\title{
時系列高分解能衛星画像を用いたラオス北部の焼畑モニタリング
}

\section{Slash and Burn Monitoring using Temporal High Resolution Satellite Data in Northern Laos}

\author{
長 澤良太・アワード・キショール・サー・山下＼cjkstart恵 \\ Ryota NAGASAWA, Awadh Kishor SAH and Megumi YAMASHITA
}

\begin{abstract}
There has been a large amount of slash and burn agricultural activity from ancient times in Northern Laos. This study focuses the environmental impact of slash and burn on the forest ecology by mean of spatial and temporal analysis of high resolution satellite data. A Geographic Information System (GIS) was also used for analyzing the relationship between the slash and burn and forest vegetation, topography and social factors. Then, the sustainability of slash and burn was examined by the ecological analysis of the shifting pattern and fallow duration derived from the image interpretation. As a result of study, a total of 89,000 ha of slash and burn fields within 172,000 ha of fallow lands were detected during the past 10 years. Although the recent increase of population pressure caused an expansion of slash and burn fields (11,000 ha in 1987 to 19,000 ha in 1997), most parts (80\%) of those fields are still maintaining the traditional conditions of having more than 7 years fallow duration. It can be said that such slash and burn is sustainable because of its ecologically balanced cycle of cultivation. Based on the analysis, it is concluded that slash and burn agriculture is not always a cause of environmental deterioration in the study area. More important is the introduction of a well managed methodology of forest resources for future sustainable development. In this sense, it can be recommended that remote sensing and GIS technology play a more important role in the monitoring of slash and burn agricultural practices.
\end{abstract}

\section{1 はじめに}

焼畑は，熱带地域のいたるところで昔より延々と繰 り返されてきた伝統的農耕のひとつである。その多く は自然の生態系のなかで展開され，自然のリズムにも とづく土地の回復と文化・社会的特性のバランスのう えに成り立ってきた農法であった（井上 1995）。この 伝統的農業が熱带林消失の元凶として，一国あるいは 熱帯地域での大きな環境問題となったのは，長い焼畑 の歴史からみればつい最近のことである。しかしなが

株式会社パスコインターナショナル

環境資源調査部リモートセンシンググループ

Remote Sensing Group, Department of Environmental Resources Survey, PASCO International Inc.

テ154-0011 世田谷区上馬3-7-8，(株)パスコインターナ ショナル

TEL 03-3413-9321 FAX 03-3413-9805

「写真測量とリモートセンシング」VOL. 37，NO. 5， 1998
ら、その実態が十分に把握されたうえでの議論は少な い。

焼烟耕作の形態は多岐にわたっており，森林に与之 る影響の度合いも多様である。このような焼畑の多様 性と環境問題との連関性を明らかにするためには，ま ず焼畑の空間的分布とその時系列的変化を把握するこ とが重要である。従来，焼畑の問題は民族地理学や村 落社会学の領域で研究されてきたが，その対象は焼畑 村落の社会構造とその変容を人文・社会学的に捉える ことが中心で，焼畑の広域的な分布や森林生態系との 関係については，把握ツゥールがなかったこともあっ てあまり目が向けられなかった。今後，地球環境や開 発途上国の地域環境が多く論じられていくうえで, 焼 畑の時空間的な把握はひとつの大きな環境研究の課題 になると同時に，従来から焼畑研究を行ってきた人 文・社会系の研究者には貴重なデー夕を提供し得るも のである。

そこで，筆者らは今なお多くの焼畑が分布するラオ 又北部において，多時期にわたる高分解能衛星画像を 
用い，焼畑の分布と変化・移動のパ夕ーンが把握でき るようなデータの作成を行った。抽出された焼畑とそ れを取りまく植生，地形，社会環境条件との関係につ いては，GIS (地理情報システム)を用いて焼畑が生じ る「場」を中心に考察した。そして，時采列解析によ り明らかにした焼畑耕作地の輪廻と周期性の問題につ いて論じ，人間一環境系のなかでその持続可能性につ いて言及した。

\section{2 ラオス北部の焼畑の概要}

本研究で対象とした地域は, ラオス人民共和国の北 部，ルアンプラバン州の州都で世界遺産に指定されて いる古都，ルアンプラバン市を取りまく山岳地域であ る(図 1 参照)。解析を行ったのは, この地域を撮影し たSPOT 衛星 (K263/J310) の範井（約34万 ha）で, 行政的な州全体はカバーされていない。

\section{1 焼畑の定義}

焼畑には様々なタイプがあり，それは民族，伝統文 化, 自然環境などの要因によって規定されている。こ こでは, 井上（1995）の分類に従い, 大きく伝統的焼

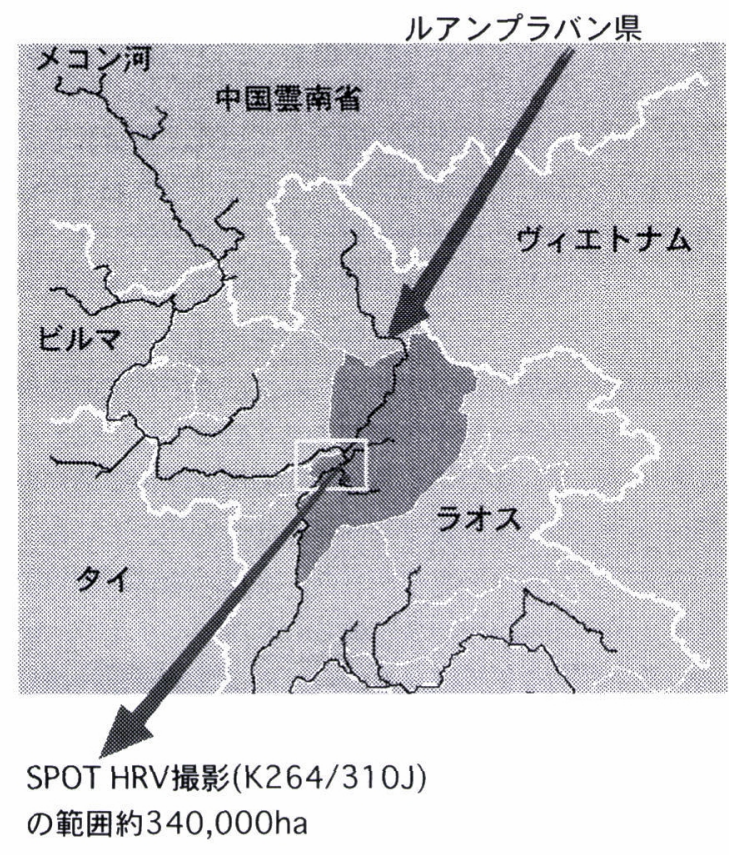

図 1 調查地域の概念図
畑と非伝統的焼畑に大きく分けて考之る。山岳民族に よって営まれる伝統的な焼畑は, 比較的長い休䦥サイ クルを持ち自然の森林生態系と調和した持続可能な農 業形態で, 森林消失の原因とはならない。何故ならば, 彼らの森林への関与は䆣取的なものでなく，森林を焼 いた耕作の後には必ず十分な休閑期間を取り，一定の 範囲内で周期的に移動する。休閑期間には, 熱带地域 の活発旺盛な植物活動によって森林は回復する。これ に対して，もともと低地に住んでいた土地なし農民が， 近年の社会構造の変容から山地に入り込み, 焼畑を行 う場合がある。これらの侵入者は，山奥というよりは むしろ山裾に多く, 森林を焼き払った土地を恒久農地 として扱い, 地力が衰えるまで酷使し, 最終的には放 棄して荒れ地となる。そこでは，森林に回復すること は困難である。

\section{2 ラオス北部の焼畑分布の特徵}

ラオスにおける焼畑面積は, FAOの統計によると 283,780ha（1988）で, 約 250,000 世帯で焼畑耕作を営 んでいる。州別の統計では, 今回の対象地域が属する ルアンプラバン州が約 $56,000 \mathrm{ha}$ (焼畑面積率 $3.1 \%$ ) で 最も多く,さらに焼畑全体の $70 \%$ 以上はラオス北部の 7 州に集中している。

ラオスにおける焼畑の実際は, 民族と自然環境条件 に規制されている。すなわち，ラオス北部は山岳地が 広く、まとまった農耕地を提供できるような平野はほ とんど見られない。この地域ではモン族, ヤオ族が伝 統的に焼畑を行ってきており，自分らの住む集落から

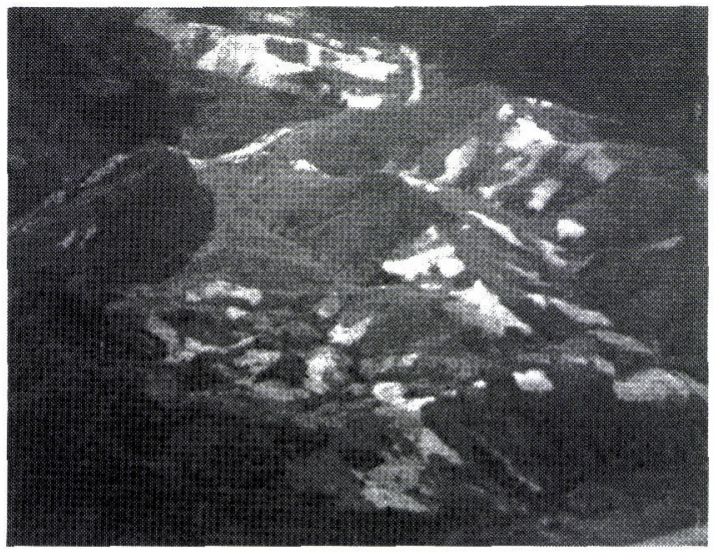

写真 1 焼畑の空撮写真 
一定の周囲で森林を焼き払い耕地を得ている（写真 1 参照）。焼畑は基本的に集落共同体（コミュニティー） を単位とした活動で, 1 集団が $8 \sim 15$ 家族で構成され ている。ひとたび耕作してから次に同じ土地を耕作す るまでの周期は 10 年程度であり，この間に 1 家族あた ク10〜30ha の土地（焼畑）を必要とし，1 集団あたり では数 100 ha を必要とする。

この伝統社会において，近年特に問題とされている のが人口圧の増加である。伝統的な焼畑社会であって も, そこに急激な人口の増加があり元来の焼畑の休䦥 サイクルに負荷がかかると，それまでの自然（森林） 一人間 (生産活動) 系のバランスが崩れ, 休閑期間が 短縮化したり，新たな森林（天然林）が焼かれたりし て環境破壊が発生する。この問題こそが本研究で焼畑 のモニタリングが必要と考えた理由のUとつである。

\section{3 時系列画像データの処理と GIS 解析}

焼畑は一定の休閑期間を持って毎年移動するため に，その現象を復元するには時系列的な解析が不可欠 である。対象地域の焼畑は通常 $7 \sim 10$ 年程度の休閑周 期を持つと言われているので，最短でも10年間にわた るモニタリングが必要である。そこで, 本研究では 1997 年から1987年までの10年間に遡って高分解衛星画像の 検索を行い, 表 1 に示すような SPOT/HRV, LAND$\mathrm{SAT} / \mathrm{TM}, \mathrm{JERS} / \mathrm{VNIR} の$ 各センサーデータから 7 時期の雲なし画像デー夕を入手した。季節的には，対 象地域の焼畑の収穫が終わる12月頃から翌年, 森に火 が入る直前の 2 月頃 (乾季) のデー夕をできるだけ得 るようにした。

\section{1 画像判読と焼畑分布の特性}

幾何補正の後, 疑似カラー合成した 7 時期の画像 データについて，ディスプレイ上で目視判読により焼 畑を抽出した。耕作の終わった焼畑はたいていの場合 裸地化しており，色調のみからは常畑や荒れ地との区 別がつきにくい。そこで, マルチウインドウを用いて 判読対象の画像に前後する時期の画像を同時に表示 し, 時系列的な変化に留意できるような判読を行った。 また，10万分の 1 の地形四から作成した DEM も併用 し，焼畑の分布する傾斜地の部分に特に注目した。

焼畑は除草などの重労働を伴う作業であるため，1 世帯での平均耕作面積は 2 ha 以下である。これが通 常15世帯前後のコミュニティーで行われているので, 上空から塊として捉えた場合, 30ha 程度のユニットで 把握されることになる。このために判読に際する画像 の解像度としては, SPOT/HRVの場合で 1 辺が 20 30ピクセルの焼畑地域を抽出するよjにした。こ れは, ディスプレイ上の目視判読で十分対応できる大 きさである。

図 2 は対象地域の時系列的な焼畑分布図で, その面 積集計結果を表 2 に示す。1987年に約11,000ha であっ た焼畑がこの10年間に増加の一途を辿り，1997年には 約19,000ha に達している。焼畑の面積占有率でみる と，3.2\%から $5.6 \%$ まで増加しているが，その増加の 加速度は最近幾分低下傾向に向かっている。また， 7 時期に抽出されたすべての焼畑を重ね合わせ，この10 年間中の 7 耕作年に焼畑に供された土地の面積を求め ると約 89,000 ha となり, 全面積の $1 / 4$ 以上が焼畑耕 作地であることが明らかになった。

表 1 使用した衛星画像データのリスト

\begin{tabular}{|l|c|c|c|c|}
\hline \multicolumn{1}{|c|}{ センサーの種類 } & 取得年月 & 間隔 & パス $(\mathrm{K}) /$ ロウ $(\mathrm{J})$ & 解像度 \\
\hline \hline SPOT-HRV & 1987年 2月27日 & & $\mathrm{K} 264 / 310 \mathrm{~J}$ & $20 \mathrm{~m}$ \\
\hline LANDSAT-TM & 1989年 3 月25日 & 25カ月 & $\mathrm{P} 129 / 046 \mathrm{R}$ & $30 \mathrm{~m}$ \\
\hline SPOT-HRV & 1990年12月12日 & 21カ月 & $\mathrm{K} 264 / 310 \mathrm{~J}$ & $20 \mathrm{~m}$ \\
\hline LANDSAT-TM & 1993年12月25日 & 36カ月 & P129/046R & $30 \mathrm{~m}$ \\
\hline SPOT-HRV & 1994年10月21日 & 10カ月 & $\mathrm{K} 264 / 310 \mathrm{~J}$ & $20 \mathrm{~m}$ \\
\hline JERS-VNIR & $\begin{array}{r}\text { 1995年12月28日 } \\
\text { 12月29日 }\end{array}$ & 14カ月 & $\begin{array}{l}\mathrm{P} 125 / 267 \mathrm{R} \\
\mathrm{P} 126 / 267 \mathrm{R}\end{array}$ & $18.4 \mathrm{~m}$ \\
\hline LANDSAT-TM & 1997年 2 月 3 日 & 14カ月 & P129/310J & $30 \mathrm{~m}$ \\
\hline
\end{tabular}



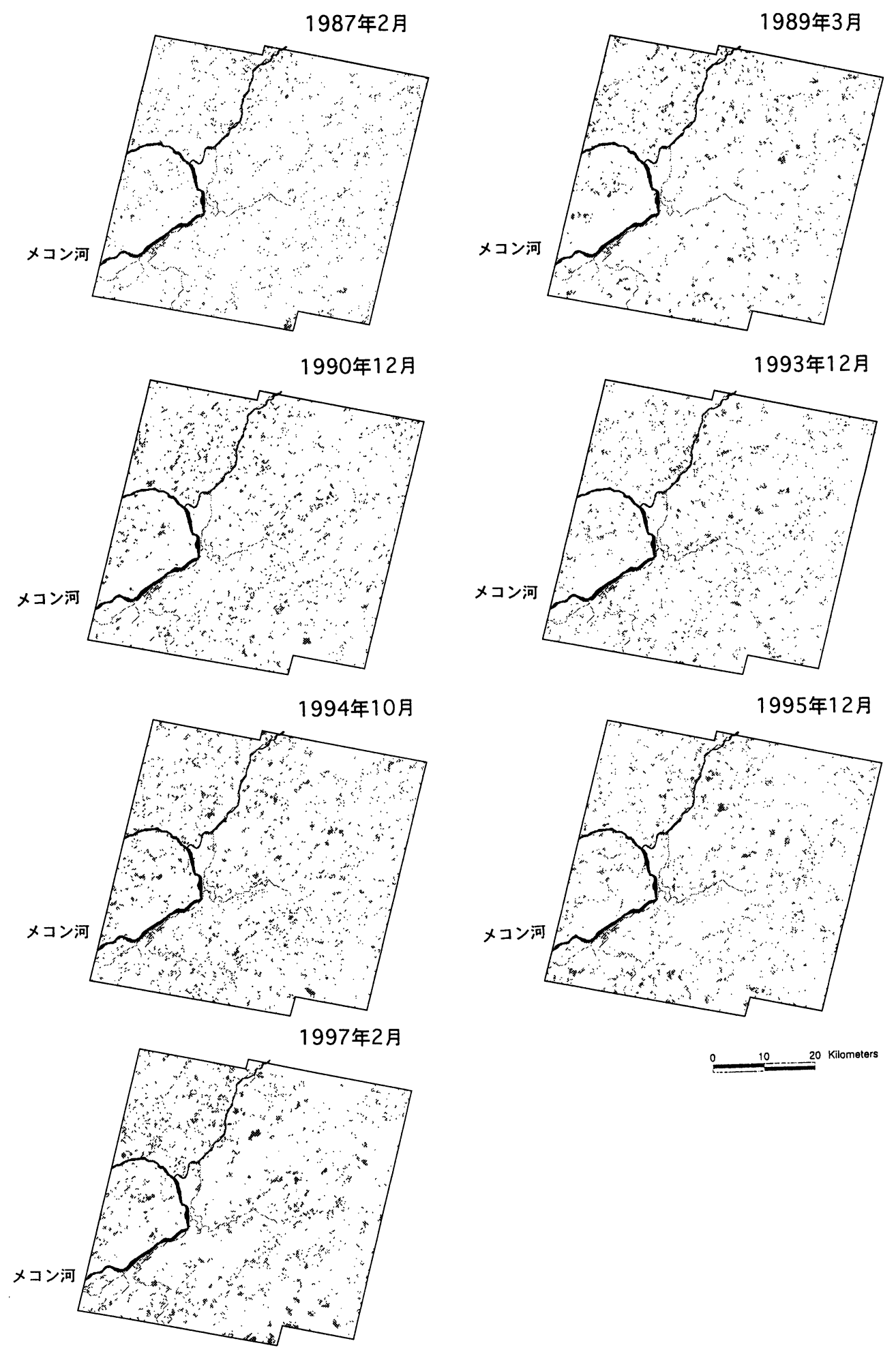

図2 時系列衛星画像の判読による焼畑分布図 
表 2 焼畑面積の時系列変化

\begin{tabular}{|c|c|c|c|c|c|}
\hline 時期 & 間隔 & $\begin{array}{c}\text { 判読対象 } \\
\text { 地域(ha) }\end{array}$ & $\begin{array}{c}\text { 焼畑面積 } \\
\text { (ha) }\end{array}$ & 焼畑面積率 & $\begin{array}{c}\text { 期間増加 } \\
\text { 面積(ha) }\end{array}$ \\
\hline \hline 1987年 2月 & - & 341,648 & 11,053 & $3.23 \%$ & - \\
\hline 1989年 3 月 & 25力月 & 341,648 & 14,300 & $4.19 \%$ & 3.247 \\
\hline 1990年12月 & 21力月 & 341,648 & 14,605 & $4.27 \%$ & 305 \\
\hline 1993年12月 & 36力月 & 341,648 & 16,044 & $4.70 \%$ & 1.439 \\
\hline 1994年10月 & 10力月 & 341,648 & 17,756 & $5.20 \%$ & 1.712 \\
\hline 1995年12月 & 14力月 & 341,648 & 18,088 & $5.29 \%$ & 332 \\
\hline 1997年2月 & 14力月 & 341,648 & 19,102 & $5.59 \%$ & 1.014 \\
\hline
\end{tabular}

\section{2 焼畑の「場」としての植生条件}

対象地域は東南アジア大陸部の内陸山岳地にあっ て, 大局的には熱帯, 亜熱带性の常緑, 落葉の混交林 が被っている。焼畑との関連で植生をみる場合, そこ が天然林か 2 次林であるかを区分することがまず重要 である。伝統的な焼畑の場合，1年間耕作に供した土 地はその後 $7 \sim 10$ 年の間休閑地となる。この間に, 火
入れが行われた木々は樹高 7 〜 $\mathrm{m}$ の 2 次林として 再生し, 休䦥林を構成するようになる。しかしながら, 休閑林は多くの場合樹冠密度が $20 \%$ 以下の落葉・混交 林, 竹林からなる開放林であり, 常緑や落葉・混交の 樹冠で覆われた閉鎖林から構成される天然林とは異な る。

本研究では時系列 NDVI值を用いて森林区分を試

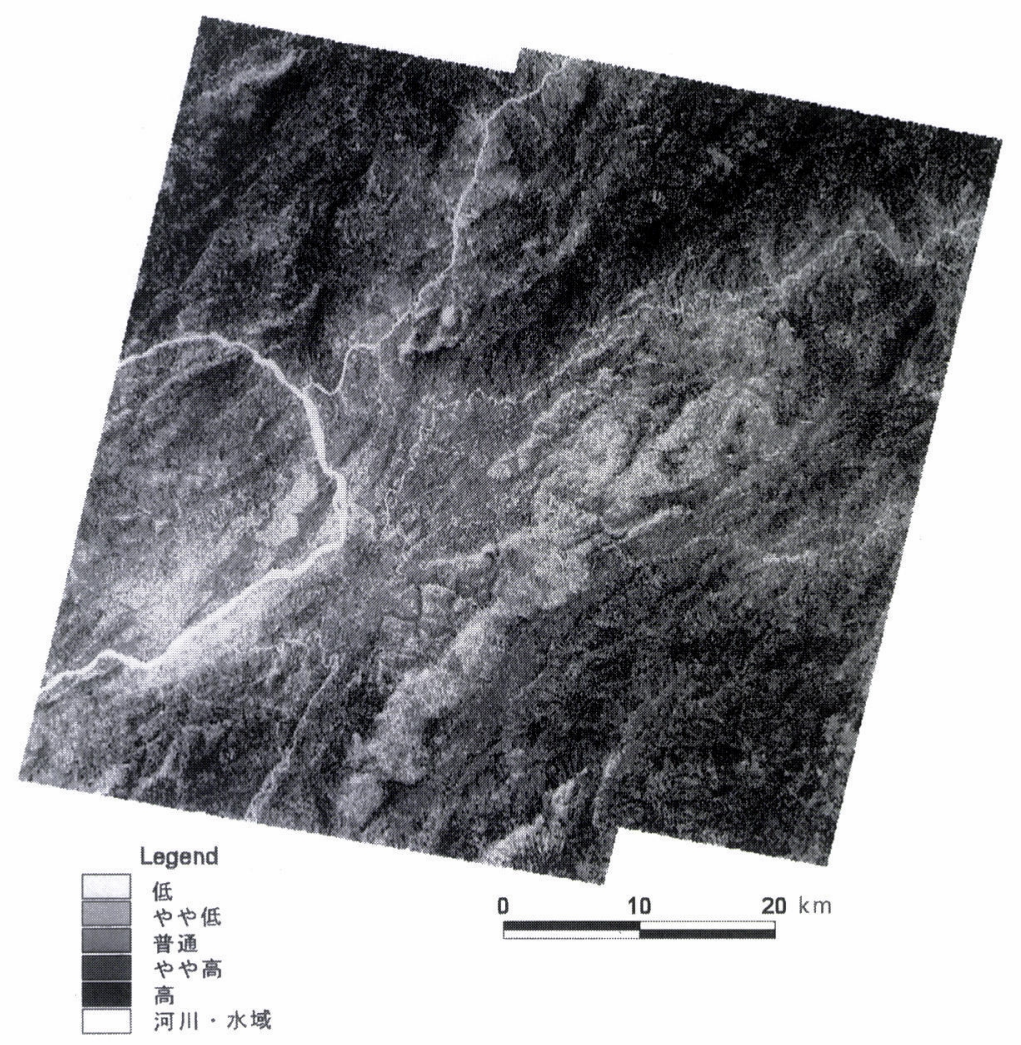

図 33 時期の NDVI 合成画像 
みそれと焼畑分布との関係について考察した。ここ で必要とされる森林区分とは，焼畑の分布筒所が休閑 林か天然林かという「場」の問題であるので, 丙者を 樹幹密度の差から区別化した。解析には 3 時期分の SPOT 画像を用いたが，その理由として，単時期の画 像では NDVI 值に季節的な影響があらわれることそ の画像が撮影された年に行われていた焼畑の影響を取 り除き，できる限り自然の条件下での植生を復元する ためである。困 3 は，1987年，90年，94年の 3 時期の 画像から求めた NDVI 值を合成し, その結果を既存の 植生図を参照しながら常緑林 (天然林) の分布に近づ くようしきい值を設定して 5 ランクに区分したもので
ある。四中，「やや高」と「高」に区分されたところが 天然林の分布とよく対応し，その面積は 138,000 ha で 全体の約 $40 \%$ に相当する。一力,「普通」や「やや低」 の範囲は開放林 (休閑林) に対応していることが既往 の森林インベントリの結果との比較から認められた。 このようにして, 対象地域には約 172,000 ha の休閑林 (全体の約 $50 \%$ ）があり，焼畑の「場」を提供している ことが明らかになった。

\section{3 焼畑の「場」としての地形条件}

東南アジア大陸部の焼畑は山岳地域にあって, 傾斜 地の森林を農民の手作業によって切り開いた土地であ

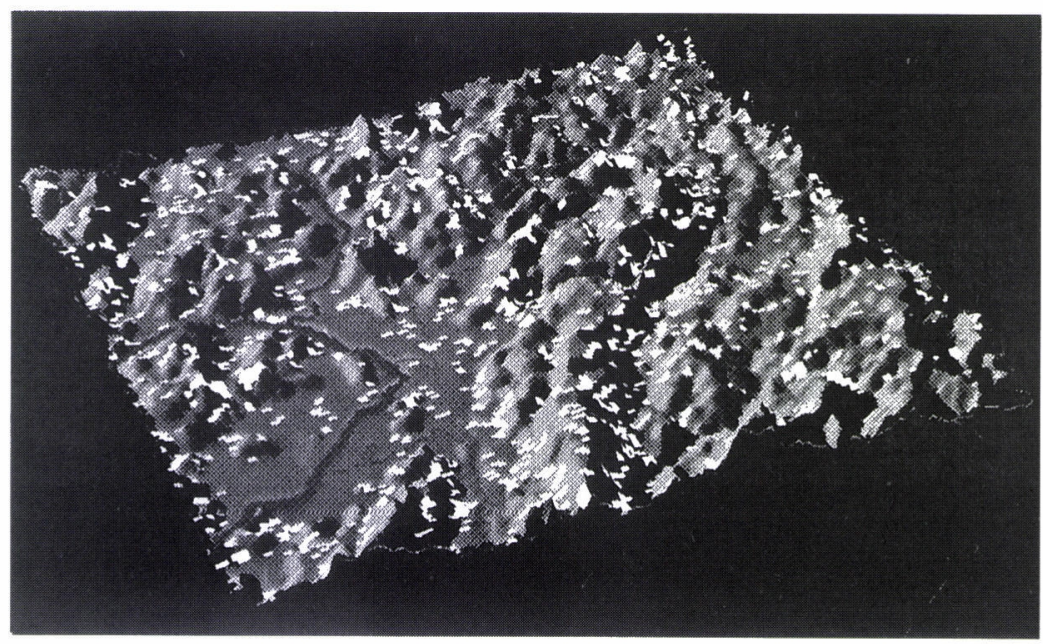

白い部分が焼畑を表す。

図 4 焼畑分布と地形標高モデル

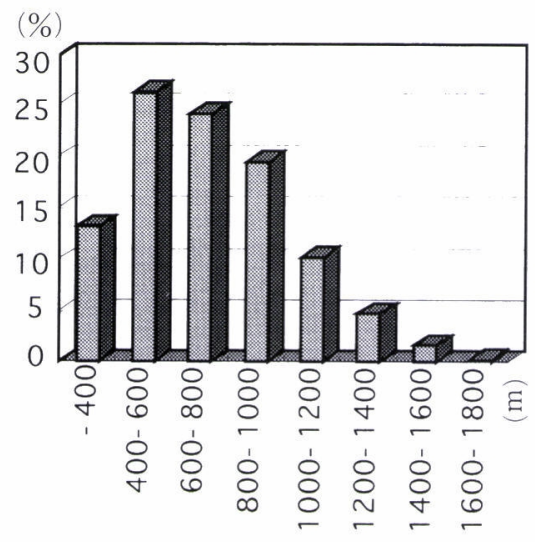

標高との関係

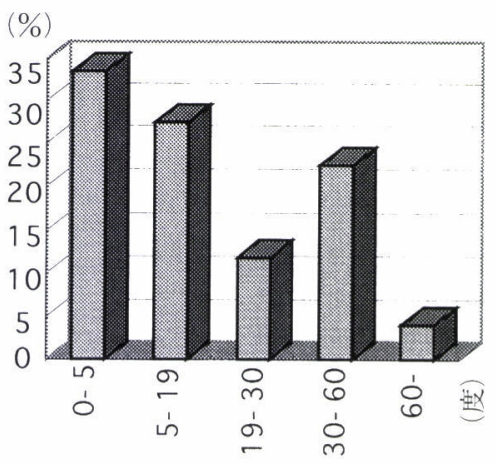

平均傾斜との関倸

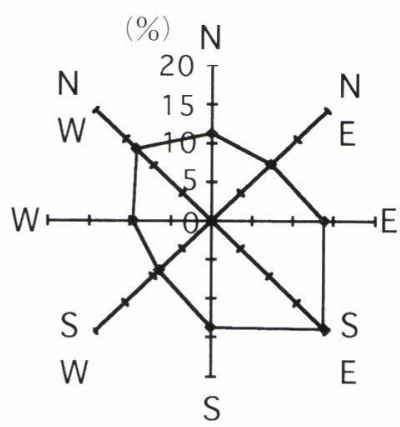

斜面方位との関係

図 5 焼畑分布と地形条件 
る。開墾後の除草や収穫等は極めて重労働で, その分 布は地形条件に大きく規制されると考えられる。そこ で，本研究では縮尺 10 万分の 1 地形図から $100 \mathrm{~m}$ 間隔 の等高線をディジタイズして DEM (地形標高モデル) を作成し, 判読で抽出された焼畑分布と重ね合わせ, 焼畑と地形との関係を解析した (図 4 参照)。

図 5 の面積集計結果によると, 対象地域の焼畑は標 高400 1,000mの地域に全体の $83 \%$ が分布し，これは ラオ・トゥン (モン族) やラオ・スーン (ヤオ族) の 山岳焼畑民族の居住区と一致している。標高 $1,000 \mathrm{~m}$ を越える地域は山地性降雨の影響で広く常緑林に被わ れるようになり，焼畑の分布は少なくなる。傾斜との 関係をみると，20\%以下の緩斜面が $61 \%$ と主体を占め るが，30\%を越える急傾斜地にも27\%ある。斜面方位 については, 日向斜面となる南東向きの斜面にピーク が現れている。

\section{4 焼畑の「場」としての社会条件}

焼畑分布の特性が文化・伝統, 民族, 経済, 交通ア クセス等の社会構造条件と如何に関係するか明らかに するためには，焼畑村落ひとつひとつの詳細な社会調 查の結果に期待するほかにない。その因果関係は, 自 然環境条件よりはるかに複雑であろう。山岳民族によ る伝統的焼畑の場合, 耕作地は毎年移動（周期）する が集落自体はまず移動しない。これは, 焼畑自体が地 域生態系のバランスなかで持続可能な状態にあること をあらわしている。そこで, 既往の定住集落と焼畑分 布との位置関係を検討した。定住集落は1969年の地形 四から抽出して GISに入力し, 集落から $500 \mathrm{~m}, 1 \mathrm{~km}$, $2 \mathrm{~km}$ のバァファーを発生させて, この範囲にある過 去10年間の焼畑面積を集計した。その結果は図 6 に示 すように，全体の75\%の焼畑は既往集落から $2 \mathrm{~km}$ バァファー内にあり, 焼畑が毎年休閑林のなかを移動 する範囲は生活共同体としての村を中心に $2 \mathrm{~km}$ 圈内 であることがわかる。このことからも，对象地域内の 大半の焼畑は伝統的なものであることが推定される。

\section{4 焼畑の時系列的解析}

時系列的な衛星画像を用いた焼畑モニタリング手法 によって, 焼畑という人間の生産活動が地域の環境(自 然生態系) に如何に影響を及ぼすかについて考察を進 める。これによって, リモートセンシング研究の立場

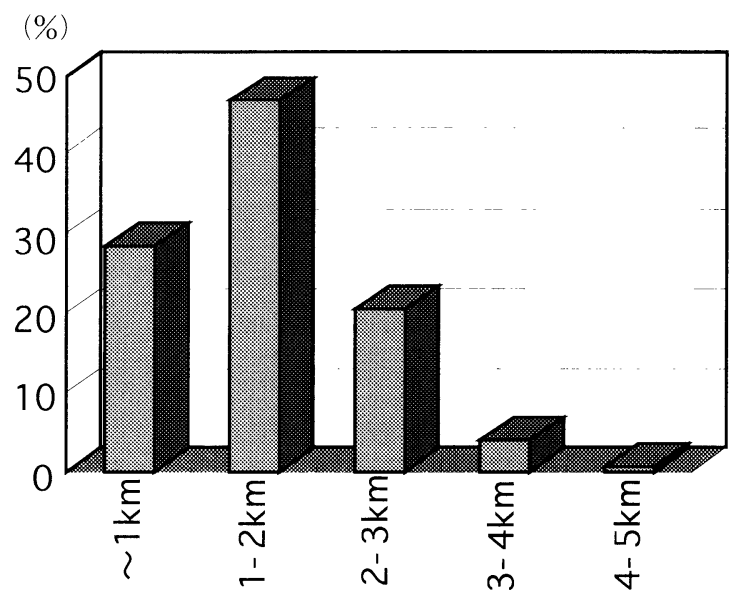

図 6 焼畑分布と集落バッファーとの関係

からどこまで地域の環境問題を議論できるかという点 にアプローチする。

\section{1 焼畑の輪廻と植生の回復}

焼畑が休閑林のなかに分布し，十分な休閑期間を保 ちながら存続することは自然の生態系にかなった生業
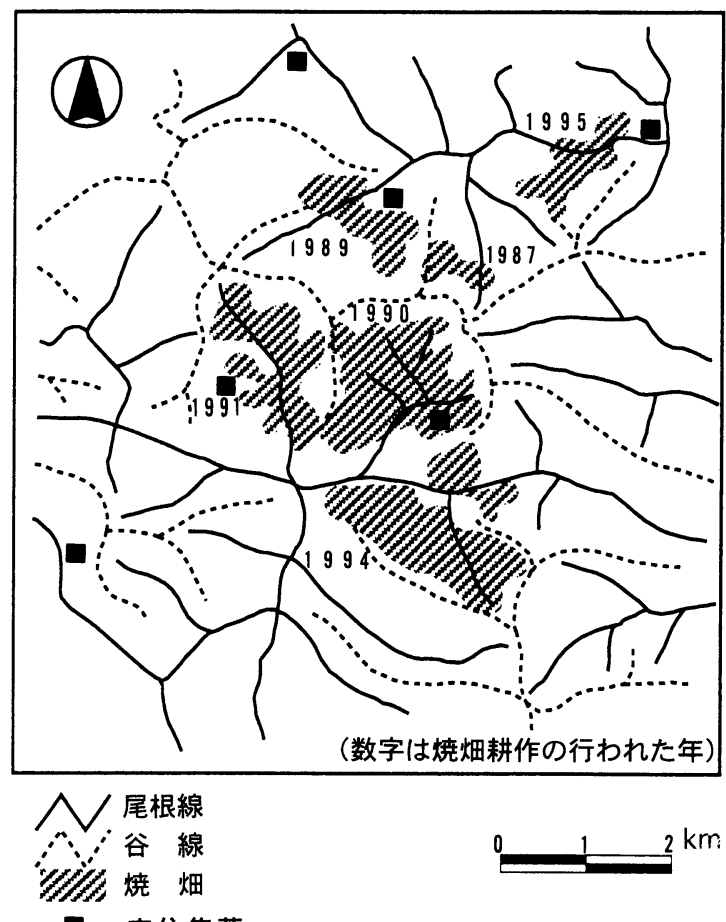

図 7 典型的な焼畑の輪廻 
であるといえる。ところが，人口圧の増加によって休 閑期間が短縮化し，焼畑が休閑林の外側に飛散し天然 林が焼かれることによって森林破壊が発生している。 近年の環境論議のなかには, 原住民の焼畑を熱帯林消 失の元凶とし，焼畑対策が急務であるとする指摘があ る。しかしながら, 焼畑イコール環境破壊という短絡 的な図式を描く前に, 実際の焼畑の時空間分布と自然 生態との関係を検討してみる必要がある。本研究では, 高分解能の時系列データの特徵を利用して, Uとつひ とつの焼畑の輪廻とそれが後に休閑地となって植生 （休閑林）が回復していく過程を NDVI 值から推定し た。

図 7 は, 典型的な焼畑地域の一例として, 標高約 1,060m の尾根上に位置する Senkoun 集落を中心に 囲む焼畑を示したものである。ここでは，1990年より 焼畑の面積が拡大し (約200ha), Uとつの小尾根が すっかり焼かれて耕地となっている。しかしながら， その耕作は毎年 1 年限りで順次隣接する斜面へ移動 し，畑は休閑地となっていく。この地域で各年に焼畑 が行われた筒所の NDVI 值の時系列変化を見ると（四

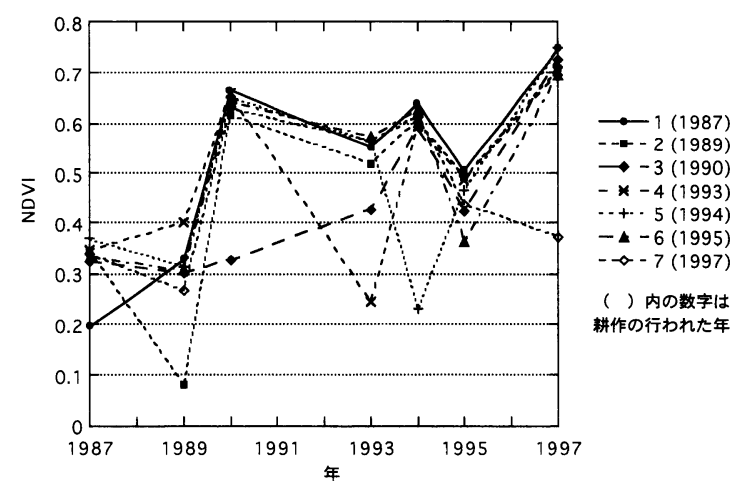

図 8 焼畑・休閑地の NDVI 值の時系列変化

8 参照), 焼畑が行われた年には0.1〜0.3未満の NDVI 值が数年後，あるいは翌年には通常に近い 0.5 以上の值に戻っていることがわかる(但し，1987，89， 95年の值は全体的に NDVI が低い)。このことは, 焼畑 が 1 年間のみの耕作でその後充分な休閑期間がある限 り，植生は充分に回復することを示している。他の幾 つかの焼畑地域でも同様の検討を行ったが，火入れが

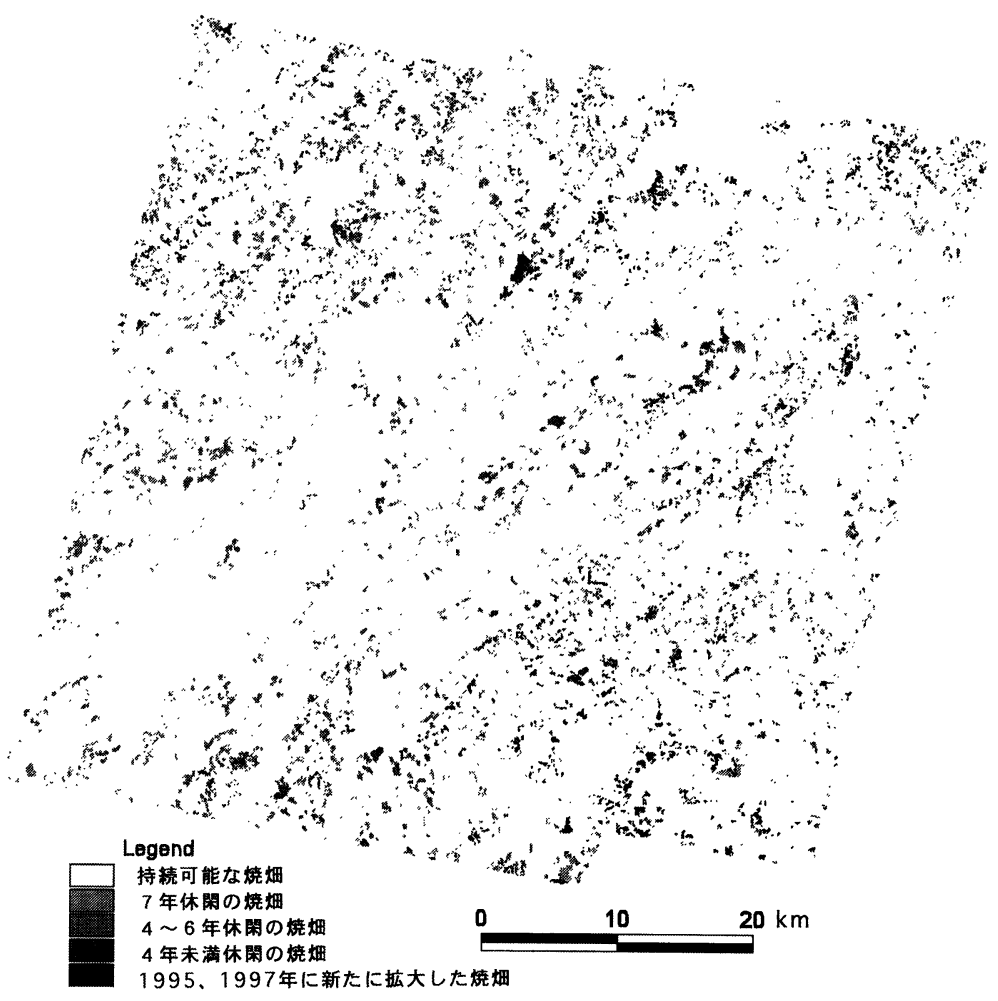

図 9 焼畑の持続可能性評価 
なされた畑でもその後休閑された地域では焼畑以前と 同様の植生に戻っていることが明らかになった。

\section{2 焼畑の持続可能性の評価}

持続可能な焼畑農業とは, 周囲の森林との間で生態 系バランスを維持しながら，森をこれ以上破壊するこ となく生業を存続させ得ることである。この持続可能 性は，焼畑が行われる「場」の環境と休閑の周期に密 接に関連している。この休閑周期を捉えるためには，

これまで特定の焼畑村落について詳細な社会調査を行 なわれてきた。しかしながら，この調査手法には多大 な労力を要するうえに, 調查地域へのアクセスなどの 問題から広域且つ多数のサンプルを対象とすることが できない。特に，地域生態系のなかで現象を捉えよう とする視点からは，空間的にある程度広い地域を対象 に時系列的なデータの利用が必要である。

図 9 は，1987年から 97 年にわたる 7 時期の衛星画像 の判読によって抽出した焼畑をすべて重ね合わせて休 閑周期を読み取り，さらに植生型との関係を考慮して 分類した焼畑分布図である。ここで持続可能な焼畑と したのは，過去 10 年間の画像で 1 時期のみの焼畑が認 められたところで，現時点で休閑期間の短縮化は起こ していない。このタイプの焼畑は約 $66,600 \mathrm{ha}$ あり, 7 年以上の休閑期間が確認された約 $5,000 \mathrm{ha}$ の焼畑と合 わせて全体の $80 \%$ を占め，伝統的焼畑とみなすことが できる。しかしながら, 約 $8,800 \mathrm{ha}$ の焼畑は休閑期間が 4 年になっており，また約 4,100 ha の焼畑が 97 年に新 たに天然林のなかで行われた。このように，森林破壊 を起こしている事実も認められる。これらの非持続的 な焼畑が分布する「場」の条件は，主に天然林の地域 で，地形的には従前の焼畑分布域よりも幾分標高の高 い $1,000 \mathrm{~m}$ 前後の山地斜面に最も多い。これらの非持 続的焼畑については，今後対策を講じるための現地調 査が必要で，その前段階として問題地域の同定する衛 星画像解析の果たす役割は大きい。

\section{3 焼畑の時空間変化}

焼畑が持続的であるか否かは，その焼畑地域を取り まく地域の変容を時間的に捉える必要がある。図10は, 焼畑地域の時空間変化と植生破壊との関係を模式的に 示したものである。図中，いちばん外側の範囲が天然 林で，そのなかに広く休閑林が散在している。ひとつ ひとつの休䦥林地域の中心には村落があって，それを

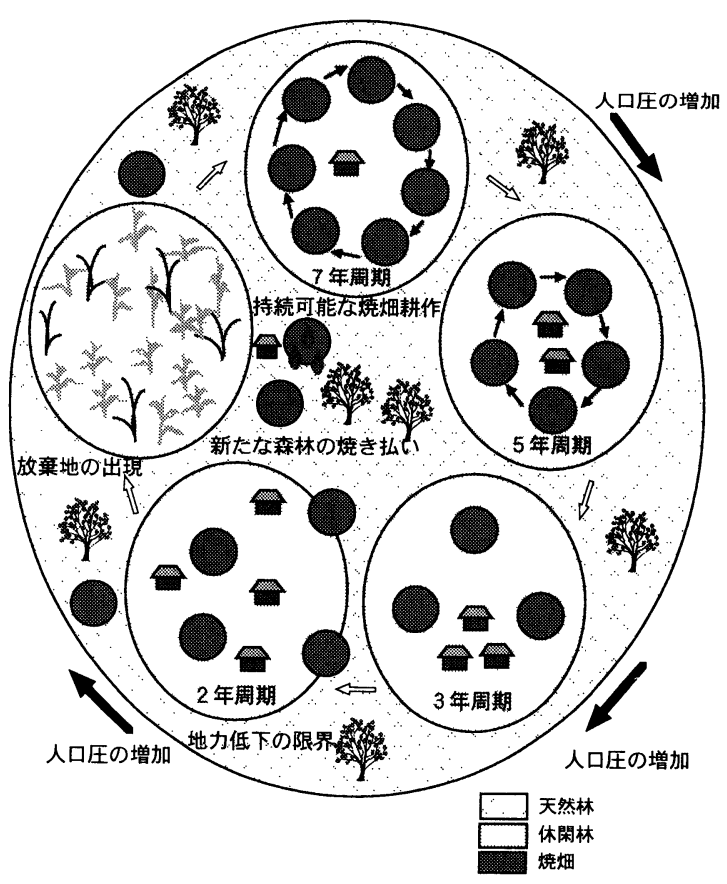

図10焼畑地域の時空間変化を示す模式図

取り囲む休閑地全体が村落共同体（ルーラルコミュニ ティ）を構成する。この休閑林のなかに焼畑があって， その場所と規模は村落共同体としての休閑地空間のな かで毎年変化する。

伝統的な焼畑は， 7 年以上の休閑周期を維持しつつ 休閑林のなかを移動する。この場合の焼畑は持続可能 な農耕形態で，新たな天然林の破壊は起きない。この 安定状態を壊すのが,「休閑林＝村落共同体」内での人 口圧の増加である。山間部でのこうした共同体はある 意味で閉鎖空間であり，食糧増産を計るためには必然 的に耕作地（焼畑）を拡大寸る。ひとつの地域共同体 (休閑林)の面積には限りがあるので, 増産を計るため には耕作の周期が短縮化し, 地力がどんどん低下して いく。こうなると悪循環で, 休閑地は最終的に放棄さ れ, 植生の回復を導く土鎄も失い, もはや休閑林（潜 在的森林）ではなくなってしまう。同時に, 村落共同 体は新天地を求めて，それまで手をつけなかった天然 林の領域に移動し，木々を伐採して耕地を作る結果と なる。

このような焼畑の発展段階を考えると，すべての焼 畑を直接的に，短絡的に森林破壊の元凶とみなすので はなく, まず各々の耕作地，休閑林，集落の組み合わ 
せからなる焼畑地域共同体がどの段階にあるのかを正 確に把握することが大切である。そのなかで，危機的 にある地域のみを抽出して，具体的な対策を講じてい く必要がある。

\section{5 保全への提言 一結語にかえて}

ラオス北部の焼畑は，稲作文化以前からアジアモン スーン地帯の伝統的な農耕文化であり，地域の自然環 境，民族，文化，風習とも結びついた生産行為である。 今，これを短絡的に森林破壊の元凶として一方的に排 除しようとしても，それは決して賢明な施策とは言え ないであろう。

森林資源枯渇の原因としては，森林管理システムの 欠如と伐採権を持つ人達の森林保全に関するインセン ティブの欠如がまず指摘される。また，森林資源の管 理計画を行うのに充分な情報, データベースの欠如に も問題がある。そのために，今後毎年の焼畑耕作地を モニタリングできるシステムを確立するとともに，そ の要因となる人口の動態も合わせて把握できる GIS データベースを構築することが提唱される。

\section{謝 辞}

本研究で用いた多量な画像デー夕, 地理デー夕の処 理過程で，(株)パスコインターナショナル環境資源調 査部 GIS グループの遠藤和志，小島由紀子两氏から惜 しみない協力をいただいた。記して感謝の意を表しま すे。

（受付日1998.2.25，受理日1998.9.14）

\section{参考文献}

1) 井上 真：焼畑と熱帯林 カリマンタンの伝統的 焼畑システムの変容, 弘文堂, pp.176, 1995

2 ）久馬一剛：焼き畑農業の生態学, サイエンス, Vol. 14, No. 4, pp.20 31, 1984

3 ）佐々木高明：東・南アジア農耕論, 弘文館, pp.517, 1989

4 ）高瀬国雄：地球環境と農林業開発の共生一焼 畑, 過放牧, 薪炭材, 土䁃劣化一の対策, 国際農林 業協力, Vol. 17, No. 1, 1994

5 ）田中 明 編：熱帯農業概論, 築地書館, pp.529, 1996

6) FAO : Assessment of the Status of Human-Induced Soil Degradation in South and Southeast Asia (ASSOD), Proceedings of the Expert Consultation of the Asian Network on Problem Soils, pp. 56, 1996

7 ) Ministry of Agriculture and Forestry, Lao P. D. R. : Forest Cover and Land Use in Lao P. D. R., Lao-Swedish Forestry Cooperation Programme -Forest Inventory Report No. 5, pp.69, 1992

$8)$ P. B. L. Srivastava : Shifting Cultivation Problems and Alternatives, FAO, pp.1-77, 1986

9 ) UNDP : Shifting Cultivation and Rural Development in the LAO P. D. R., Report of the Nabong Technical Meeting, pp.274, 1994 